\title{
UTILIZATION OF TEMPERATURE KINETICS AS A METHOD TO PREDICT TREATMENT INTENSITY AND CORRESPONDING TREATED WOOD QUALITY: DURABILITY AND MECHANICAL PROPERTIES OF THERMALLY MODIFIED WOOD
}

\author{
K. Candelier ' ${ }^{\text {, S. Hannouz }}{ }^{1}$, M. Elaieb ${ }^{2}$, R. Collet1, S. Dumarçay ${ }^{3}$, \\ A. Pétrissans3, P. Gérardin ${ }^{3}$, M. Pétrissans ${ }^{3, \oplus}$
}

\begin{abstract}
Wood heat treatment is an attractive alternative to improve decay resistance of wood species with low natural durability. However, this improvement of durability is realized at the expense of the mechanical resistance. Decay resistance and mechanical properties are strongly correlated to thermal degradation of wood cells wall components. Mass loss resulting from this degradation is a good indicator of treatment intensity and final treated wood properties. However, the introduction of a fast and accurate system for measuring this mass loss on an industrial scale is very difficult. Nowadays, many studies are conducted on the determination of control parameters which could be correlated with the treatment conditions and final heat treated wood quality such as decay resistance. The aim of this study is to investigate the relations between kinetics of temperature used during thermal treatment process representing heat treatment intensity, mass losses due to thermal degradation and conferred properties to heat treated wood. It might appear that relative area of treatment temperature curves is a good indicator of treatment intensity. Heat treatment with different treatment conditions (temperature-time) have been performed under vacuum, on four wood species (one hardwood and three softwoods) in order to obtain thermal degradation mass loses of 8,10 and $12 \%$. For each experiment, relative areas corresponding to temperature kinetics, mass loss, decay resistance and mechanical properties have been determined. Results highlight the statement that the temperature curves' area constitutes a good indicator in the prediction of needed treatment intensity, to obtain required wood durability and mechanical properties such as bending resistance and Brinell hardness.
\end{abstract}

Keywords: Control quality, decay resistance, heat treatment, mass loses, mechanical properties, temperature kinetics.

\footnotetext{
${ }^{1}$ LaBoMaP, Arts et Metiers ParisTech, Rue Porte de Paris, F-71250 Cluny, France.

2 LGVRF, INRGREF, B.P. 10, 2080 Ariana, Tunisia.

${ }^{3}$ Laboratoire d'Etudes et de Recherche sur le Matériau Bois, EA 4370, Université de Lorraine, Faculté des Sciences et Technologies, BP 70239, F-54506 Vandœuvre-lès-Nancy, France.

^ Corresponding author: Mathieu.Petrissans@univ-lorraine.fr Received: 14.01.2014 Accepted: 19.06.2014
} 


\section{INTRODUCTION}

Wood heat treatment by mild pyrolysis is used to improve wood properties such as its decay resistance and dimensional stability (Rowell et al. 2009, Poncsak et al. 2010). These improved properties result from the wood cell polymers' chemical modifications occurring during treatment (Esteves et al. 2013), which confer the new wood properties (Tjeerdma and Militz 2005). Previous studies have shown that the wood thermal degradation mass loss is a good indicator for the treatment intensity directly related to the temperature and the duration of the heat treatment (Welzbacher et al. 2007, Pétrissans et al. 2014). Elemental wood composition has been reported as a good marker of treatment intensity and consequently of the mass loss level, allowing further prediction of the heat treated wood decay resistance (Nguila et al. 2009). According to previous experiments, mass losses between 10 and $14 \%$ are generally required to reach a weight loss against fungal attacks lower than $3 \%$. The decay resistance of the treated wood matches to a full durability (Chaouch et al. 2010), according to the European Standard EN 113/A1 (2004). In parallel with improvement of wood durability, mechanical properties were generally significantly weakened (Bengtsson et al. 2002). The wood properties' modifications are directly correlated to the treatment intensity (Chaouch et al. 2010, Gunduz et al. 2009). Nowadays, the main concern is the difficulty to produce in an industrial scale heat treated wood with constant and controlled final wood product quality (durability, dimensional stability, color). Most of thermal treatment processes are performed by convection and don't record the wood mass loss during the process (Abibois 2012). Moreover, heat transfer by convection may give rise to an unsatisfactory treatment homogeneity on the set of treated samples (Pétrissans et al. 2007). So, it is necessary to elaborate some parameters to estimate the mass loss, resulting from treatment intensity, the new properties of heat treated wood, and which could be easily used for industrial process. In this study, heat treatment was performed by conduction to obtain a better thermal homogeneity. Wood mass loss was recorded during the thermal degradation. Curing was carried out under vacuum. The global treatment duration by comparison with a process using a nitrogen atmosphere (Candelier et al. 2013a) is reduced, because re-condensation and thermal reticulation of wood degradation products are avoided.

The aim of this study is to investigate the relations between the heat treatment intensity and the thermal degradation kinetics, mass losses and the final properties conferred to the heat treated wood. The relative area of treatment temperature curves is proposed as an indicator of heat treatment. This area represents the amount of the heat absorbed by the treated wood samples. Heat treatments with various intensities (temperature-time) have been performed on four wood species in order to obtain thermal degradation mass loses of 8,10 and $12 \%$. For each treatment, relative areas, masse losses, decay resistance and mechanical properties have been determined and correlated.

\section{MATERIAL AND METHODS}

\section{Wood sample and heat treatment protocol}

Each heat treatment was carried out simultaneously on two wood boards of $250 \times 25 \times 110 \mathrm{~mm}^{3}$ (L x $\mathrm{R} \times \mathrm{T}$ ). Four wood species have been studied, one hardwood; Zeen oak (Quercus canariensis) and three softwoods; Aleppo pine (Pinus halepensis), Radiata pine (Pinus radiata), Maritime pine (Pinus pinaster). Thermal treatment was performed in a 0,25 cubic meter laboratory autoclave by conduction between two electric heated metallic plates equipped to record dynamic mass loss and temperature (SEIR, Charmes France). Each board was initially dried at $103^{\circ} \mathrm{C}$ for $48 \mathrm{~h}$ and placed in the oven. The oven was then closed and placed under vacuum (200 mbar). The plate temperature was slowly increased by $0,3{ }^{\circ} \mathrm{C} \cdot \mathrm{min}^{-1}$ from ambient to the drying temperature $\left(103^{\circ} \mathrm{C}\right)$ until complete stabilization of the boards' mass. After this period, the plate's temperature was increased by $0,3^{\circ} \mathrm{C} \cdot \mathrm{min}^{-1}$ from $103^{\circ} \mathrm{C}$ to $170^{\circ} \mathrm{C}$ and the temperature maintained for $2 \mathrm{~h}$. The temperature was then increased by $0,2{ }^{\circ} \mathrm{C} \cdot \mathrm{min}^{-1}$ from 170 to $220^{\circ} \mathrm{C}$ to perform wood thermal modification to different mass losses of 8,10 and $12 \%$ (Figure 1). The heating system was then stopped and wood samples cooled down to room temperature under an oxygen free atmosphere. 


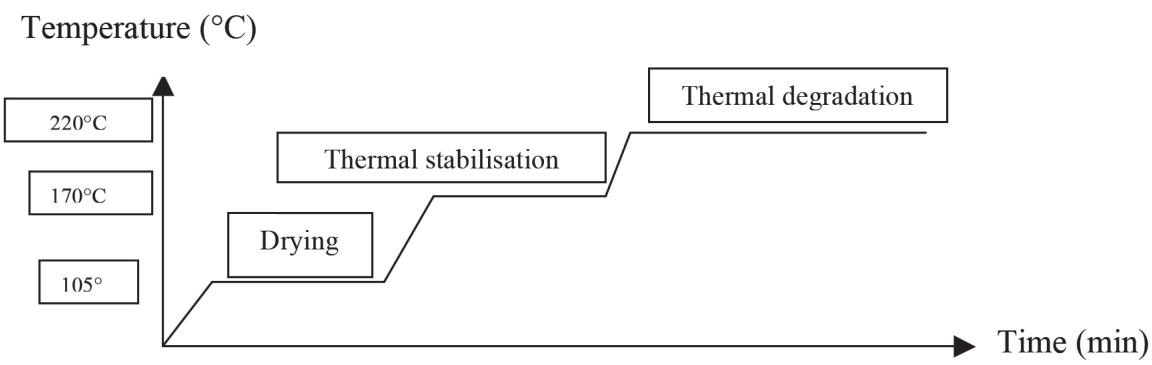

Figure 1. Temperature evolution to achieve thermal treatment.

\section{Relative area determination}

The heat treatment device allows dynamic recording of wood temperature and wood mass loss curves. Relative area was calculated between the end of the drying step at $105 \mathrm{oC}(\mathrm{m} 0)$ and the process of cooling down to $105^{\circ} \mathrm{C}$ (Figure 2). The relative area was calculated during the effective thermal modification step for each heat treatment and each wood species. The temperature curves are obtained by averaging both simultaneously treated wood boards. The relative area represents the quantity of the effective heat power exchanged during the treatment process leading to a required wood mass loss. Relative area takes into account on one hand the capacitive thermal power transferred by conduction in the oven, and on the other hand to the reaction enthalpy due to the exothermic character of the thermodegradation reactions.

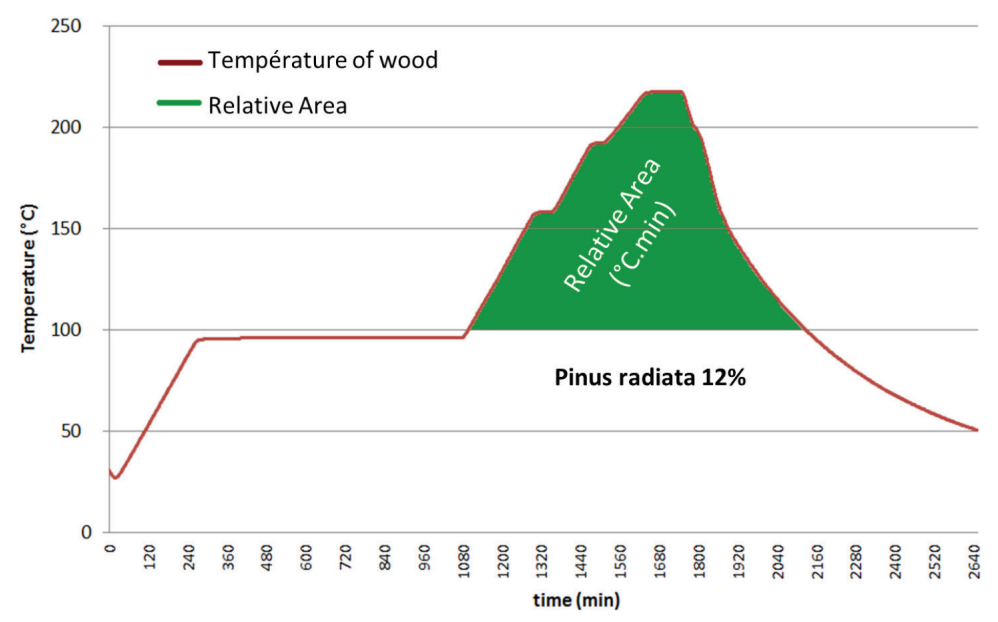

Figure 2. Relative area from temperature kinetic representing Pinus radiata heat treatment to obtain a mass loss of $12 \%$. 


\section{Decay resistance}

Blocks of $25 \times 10 \times 5 \mathrm{~mm}^{3}$ in longitudinal, radial and tangential directions were cut from heat treated and untreated wood and dried at $103{ }^{\circ} \mathrm{C}$ for $48 \mathrm{~h}\left(\mathrm{~m}_{1}\right)$. Petri dishes $(90 \mathrm{~mm}$ diameter) were filled with sterile culture medium prepared by mixing $30 \mathrm{~g}$ malt and $40 \mathrm{~g}$ agar in one $\mathrm{L}$ of distilled water, inoculated with the different fungi and incubated at $22{ }^{\circ} \mathrm{C}$ and $70 \%$ relative humidity to allow full colonization of the surface by the mycelium. The decay resistance was tested on four different fungies: Coriolus versicolor (CV), Gloeophyllum trabeum (GT), Coniophora puteana (CP) and Poria placenta (PP). Three blocks (2 treated and one untreated as control) were placed in each Petri dish and incubated during 16 weeks to evaluate the effect of thermal modification. Each experiment was triplicated. After this period, mycelia were removed and the blocks were dried at $103{ }^{\circ} \mathrm{C}$ and weighed (m2) to determine the weight loss caused by the fungal attack.

$$
W L(\%)=100 \times \frac{m_{1}-m_{2}}{m_{1}}
$$

\section{Mechanical properties}

In order to assess the effect of heat-treatment parameters on the mechanical properties, three point bending (MOE, MOR) and Brinell hardness were carried out for untreated and heat treated samples, results are compared. An INSTRON 4467 Universal Mechanical Test Machine was used for the measurements. Samples were conditioned in a room with $65 \% \mathrm{RH}$ and $22{ }^{\circ} \mathrm{C}$ during the time necessary to stabilize the samples weights.

Three point static bending tests were carried out according to the EN 408 (2003). The sample size was $200 \times 10 \mathrm{~m} \times 10 \mathrm{~mm}^{3}$ (L x R x T). The moving head speed and the span length were $1,8 \mathrm{~mm} \cdot \mathrm{s}^{-1}$ and 160 $\mathrm{mm}$, respectively. The load deformation data obtained were analyzed to determine the modulus of elasticity (MOE) and the modulus of rupture (MOR). Tests were replicated twenty times for each treatment condition, 10 samples were used for each heat treated boards.

Brinell hardness tests were performed according to the EN 408 (2003) standard. The force was applied by a sphere with a diameter of $10 \mathrm{~mm}$. This force is applied in three steps. It was slowly increased by 0,2 $\mathrm{kN} . \mathrm{s}^{-1}$ during $15 \mathrm{~s}$. After this period, a force of $3 \mathrm{kN}$ was maintained for $25 \mathrm{~s}$ and finally the applied force was decreased. Brinell hardness tests were replicated twenty times (10 tests for each wood boards). Every test was separated by at least $30 \mathrm{~mm}$ from the edge of the boards and $25 \mathrm{~mm}$ between each test. Accuracy of the measurement of the ball penetration depth was $0,01 \mathrm{~mm}$ and the applied force's one was $0,005 \mathrm{kN}$.

\section{RESULTS AND DISCUSSION}

\section{Relative area and treatment intensity}

Figure 3 gives the relations between the relative area and wood samples mass losses issued from the thermal degradation obtained for a given treatment intensity. For all wood species, heat treatment was performed at $220^{\circ} \mathrm{C}$. The difference between treatment intensities is determined by process duration. Treatment time will then determine the wood mass loss. Relative areas are representative to the treatment intensity. For a given mass loss, the relative area is determined as shown on figure 2 . The relative area corresponding to the kinetics of Zeen oak wood thermal degradation was found less important compared to the three others softwood species. These results are in agreement with previous studies (Candelier et al. 2011) that have showed the higher sensitivity to thermal degradation of hardwood than softwood. The thermal susceptibility differences between hardwood and softwood species are more pronounced for mass loss higher than $8 \%$. Similar result have been found by Chaouch et al. (2010) in a study of the correlation between mass loss and treatment intensity (time and temperature) during the heat treatment of several wood species such as silver fir, pine, beech, poplar and ash. 


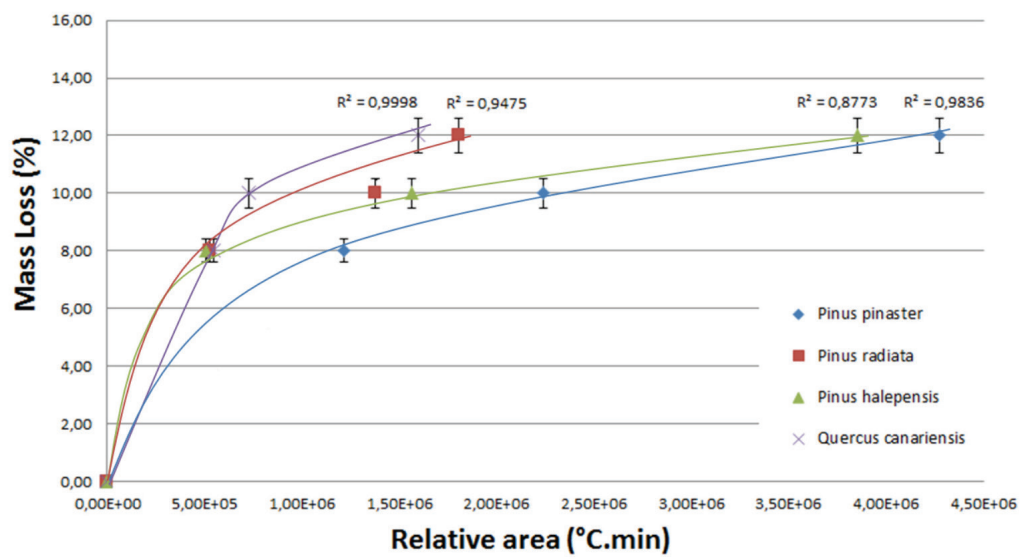

Figure 3. Correlation between Relative Area and Mass losses due to thermal degradation of different wood species.

The main difference concerns the thermal degradation kinetics, which is directly influenced by the treatment temperature (Candelier et al. 2011) and the quantity of acetic acid liberated during the heat treatment (Stamm 1956). The acetic acid production strongly depends on the wood species nature: hardwoods lead to higher amounts of acid compared to softwoods. This may be related to the nature of hemicelluloses initially present in hardwood and softwood species (Sjöström 1981, Fengel and Wegener 1989).

The observed in these work relations between the process heat energy characterized by the relative area and the occurring wood mass loss show a good agreement with a previous study based on a thermal-gravimetric device coupled with DSC analysis system (Candelier et al. 2013b).

\section{Prediction of decay resistance}

Durability of untreated and heat wood were investigated with various brown rot and white rot fungi. Similar results are obtained for each fungus: Coriolus versicolor (CV), Gloeophyllum trabeum (GT), Coniophora puteana (CP) and Poria placenta (PP). Higher weight loss was caused by Poria placenta, results are presented on the figure 4 . After a 16 weeks fungal exposure, all heat treated samples show an improved decay durability revealed by the measured reduced weight losses, while untreated samples were strongly degraded. Softwood species' weight losses are greater than $22 \%$ according to the used fungal species. Zeen oak wood exhibits a higher natural durability, however thermal treatment improves further its decay resistance. 


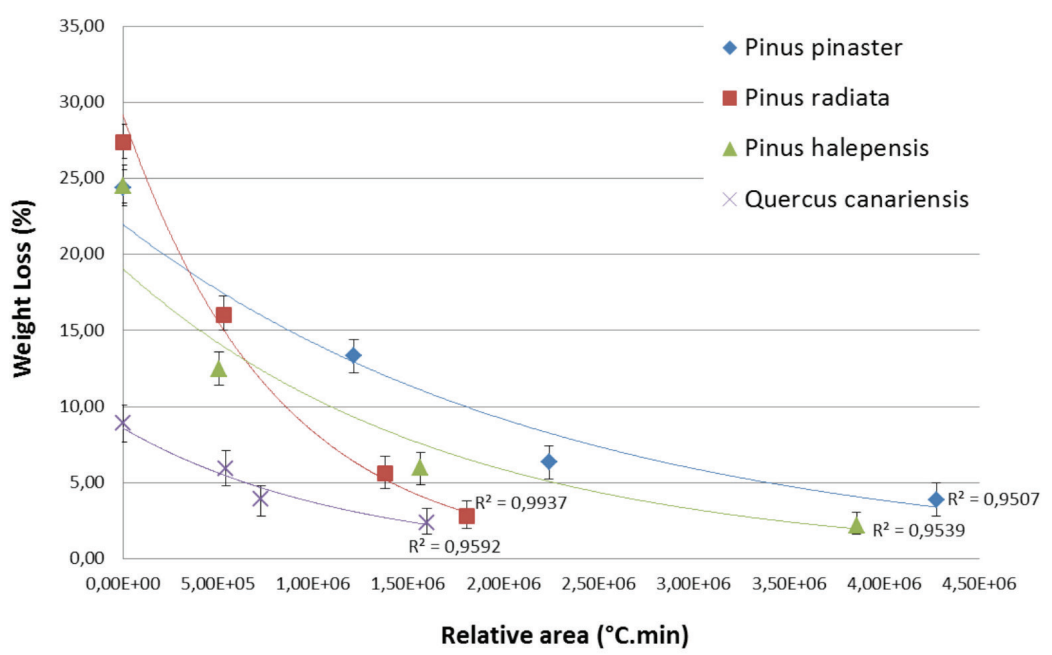

Figure 4. Prediction of Weight Losses due to Poria placenta exposure by determination of relative Area, for different wood species.

According to the determination coefficients $\left(\mathrm{R}^{2}\right)$ values comprised between 0,95 and 0,99 , the relative area seems to be a good parameter to predict final durability of the studied wood species. Moreover, whatever is the studied wood species, when a mass loss of $12 \%$ is reached, the decay resistance is improved to confer a durability class 3 . Similar results have been found by Chaouch et al. (2010) indicating that treatment intensity represented by mass loss comprised between 10 and $12 \%$ improves significantly the decay resistance of several hardwood and softwood species.

\section{Evaluation of mechanical properties}

Whatever is the wood species nature, mechanical properties are modified by the thermal treatment. Results indicate that, modulus of elasticity (MOE) is less affected after heat treatment comparatively to the modulus of rupture (MOR), while Brinell hardness is only slightly affected. Similar results have been fund by (Yildiz et al. 2006). Moreover, the decrease of these three mechanical properties seems to be correlated to the relative areas introducing the treatment intensity (Figures 5-7).

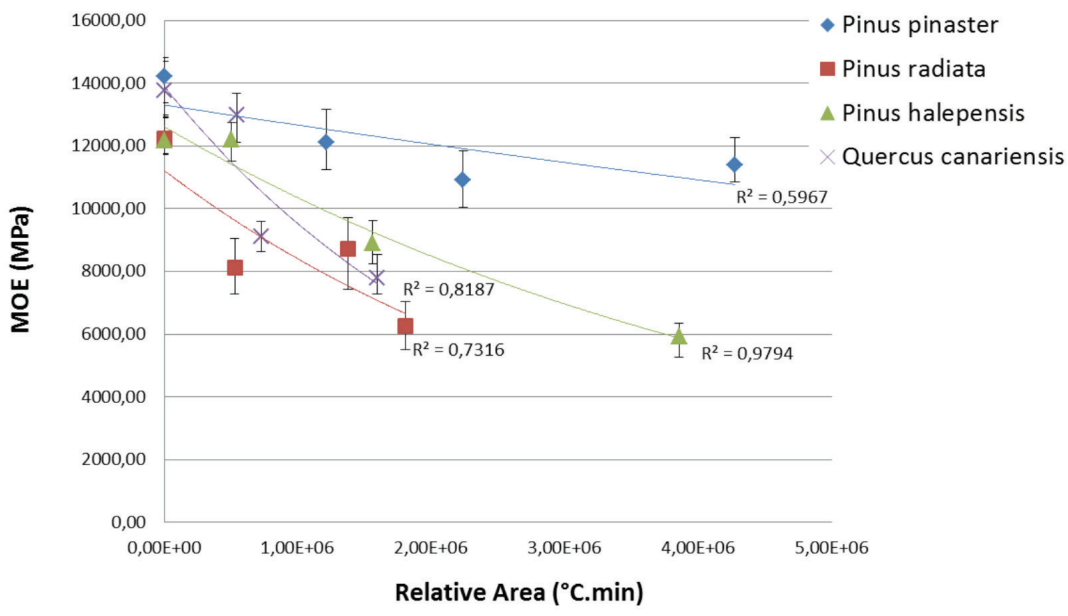

Figure 5. Determination of bending MOE by Relative Area values, for different wood species. 


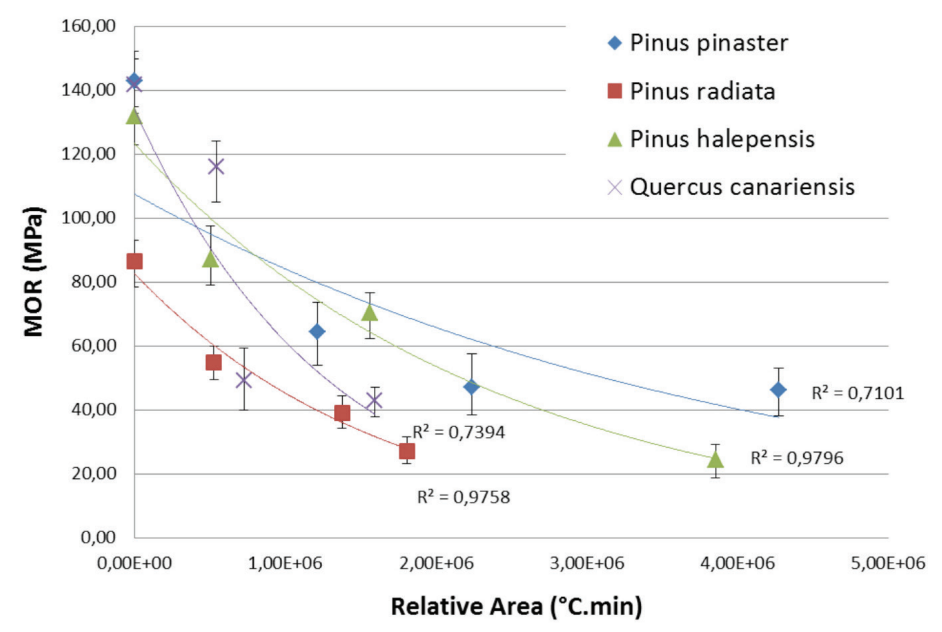

Figure 6. Determination of bending MOR by Relative Area values, for different wood species.

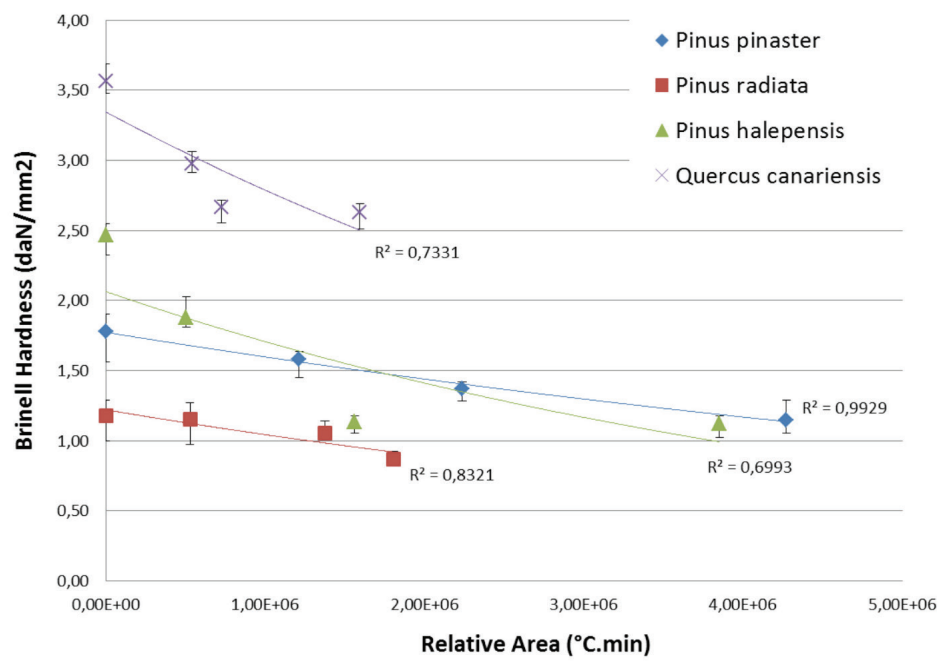

Figure 7. Determination of Brinell Hardness by Relative Area values, for different wood species.

Previous studies have indicated that MOE and MOR in Bending strength decrease as a function of the increased treatment severity (Mburu et al. 2008). In addition, the influence of heat treatment on different strength properties is not proportional (Boonstra et al. 2007). These mechanical modifications depend on the wood species nature (Arnold 2010) but also on the natural defects, such as knots, resin pockets. Wood strength properties appeared to be affected by the heat treatment (Boonstra et al. 2007). These observations may explain the scatter of results and consequently the lower value of the determination coefficients $(0,60$ $<\mathrm{R}^{2}<0,98$, Figures 5-6). 
Concerning Brinell hardness properties, Hardness decreases as a function of the increased treatment intensity (Unsal et al. 2003) and the influence of the wood nature on this hardness weakening is more pronounced (Figure 7). Results indicate that treatment severity causes higher hardness degradation on the zeen oak than the other softwood species. Indeed, although zeen oak wood had the highest hardness value for control samples, its hardness reduction was also larger than for any other species considered in this work. Similar results have been found through previous studies (Priadia and Hiziroglub 2013). They found also that, in the oak wood, hardness is more degraded by the heat treatment intensity than in other wood species as mindi, mahogany and pine woods. Extreme porous structure along with high extractive amount of oak would be considered for such findings. Additionally, SEM microscopic analyses (Priadia and Hiziroglub 2013) have shown that in the heat treated oak wood there are more cracks and distorted parts than in the heat treated pine. That observation can explain the higher oak wood hardness sensibility to thermal degradation compared to other species. Further studies on the relative areas could provide additional information for industrial applications giving recommendation about the heat treatment cycle consumptions, necessary for treat thermally a considered wood species to obtain desired quality of the final material.

\section{CONCLUSION}

Relative area representative to heat treatment intensity seems to be a good indicator to predict wood mass loss due to the thermal degradation. This parameter can be used also to estimate the final product quality. Indeed, relative area appears to be a good means to predict the durability improvement after a thermal modification of wood using a conduction process. In spite of less important correlation coefficients, mechanical properties seem to be related to the relative areas. Heat treated woods presents lower MOR and MOE in bending and lower Brinell hardness comparatively to control wood samples. Between the three investigated mechanical properties, MOR was the most sensitive property to the heat treatment conditions. However, reduction of these properties seems to be correlated with the relative area. Finally, the utilization of the relative area, as indicator of decay resistance and mechanical properties of heat treated wood, could be investigated for other industrial wood thermal modification processes such as Thermowood ${ }^{\circledR}$. While similar correlations as these found in our study could be transposed to other industrial convection processes. The relative area could be a means to control and predict heat-treated wood quality.

\section{ACKNOWLEDGMENTS}

LERMaB is supported by the French National Research Agency through the Laboratory of Excellence ARBRE (ANR-12- LABXARBRE-01), the authors gratefully acknowledge this aid. 


\section{REFERENCES}

Abibois. 2012. Le traitement à haute température des bois. Le réseau des professionnels du bois en Bretagne : 11 pages.

Arnold, M. 2010. Effect of moisture on the bending properties of thermally modified beech and spruce. Journal of Materials Science 45: 669-680.

Bengtsson, C.; Jermer, J.; Brem, F. 2002. Bending strength of heat-treated spruce and pine timber. International Research Group on Wood Preservation document no. IRG/WP 02-40242.

Boonstra, M.J.; Van Hacker, J.; Tjeersma, B; Kegel, E.V. 2007. Strength properties of thermally modified softwoods and its relation to polymeric structural wood constituents. Ann For Sci 64: 679-690.

Candelier, K.; Chaouch, M.; Dumarçay, S.; Petrissans, A.; Petrissans, M.; Gérardin, P. 2011. Utilization of thermodesorption coupled to GC-MS to study stability of different wood species to thermodegradation. Journal of Analytical and Applied Pyrolysi 92: 376-383.

Candelier, K.; Dumarçay, S.; Petrissans, A.; Gérardin, P.; Petrissans, M. 2013(a). Comparison of mechanical properties of heat treated beech woods cured under nitrogen or vacuum. Polymer Degradation and Stability 98: 1762-1765.

Candelier, K.; Treu, A.; Dibdiakova, J.; Larnøy, E.; Petrissans, A.; Dumarçay, S.; Pétrissans M.; Gérardin P. 2013b. Utilization of TG-DSC to study thermal degradation of beech and silver fir. International Research Group on Wood Preservation document no. IRG/WP 13-40628

Chaouch, M.; Pétrissans, M.; Pétrissans, A.; Gérardin, P. 2010. Use of wood elemental composition to predict heat treatment intensity and decay resistance of different softwood and hardwood species. Polymer Degradation and Stability 95: 2255-2259.

EN 113/A1 Standard 2004. Produits de préservation du bois - Méthode d'essai pour déterminer l'efficacité protectrice vis-à-vis des champignons basidiomycètes lignivores - Détermination du seuil d'efficacité [France].

EN 408 Standard 2003. Structures en bois - Bois de structure et bois lamellé-collé. Détermination de certaines propriétés physiques et mécaniques [Austria].

Esteves, B. ; Velez-Marques, A.; Domingos, I. ; Pereira, H. 2013. Chemical change of heat treated pine and eucalypt wood monitored by FTIR. Maderas. Ciencia y tecnología 15 (2): 245-258.

Fengel, D.; Wegener, G. 1989. Wood - Chemistry, Ultrastructure, Reactions. Berlin, Germany, Walter de Gruyter, Chapter 12 (Influence of Temperature): 319-344.

Gunduz, G.; Aydemir, D.; Karakas, G. 2009. The effects of thermal treatment on the mechanical properties of wild Pear (Pyrus elaeagnifolia Pall.) wood and changes in physical properties. Materials and Design 30: 4391-4395.

Mburu, F.; Dumarçay, S.; Bocquet, J.F.; Pétrissans, M.; Gérardin, P. 2008. Effect of chemical modifications caused by heat treatment on mechanical properties of Grevillea robusta wood. Polymer Degradation and Stability 93 (2): 401-405.

Nguila Inari, G.; Pétrissans, M.; Pétrissans, A.; Gérardin, P. 2009. Elemental composition of wood as a potential marker to evaluate heat treatment intensity. Polymer Degradation and Stability 94: 365-8. 
Pétrissans, A.; Younsi, R.; Chaouch M.; Gérardin P.; Pétrissans, M. 2014. Wood thermodegradation: experimental analysis and modeling of mass loss kinetics. Maderas. Ciencia y tecnología 16 (2): 133-148.

Pétrissans, M.; Pétrissans, A.; Gérardin, P. 2007. Contrôler la durabilité du bois de hêtre traité thermiquement. Tracés, Bulletin technique Technologie du bois de la Suisse Romande 17: 12-6.

Poncsak, S.; Kocaefe, D.; Younsi, R. 2010. Improvement of heat treatment of Jack pine (Pinus banksiana) using thermoWood technology. European Journal of Wood and Woods Products 69(2): 281-6.

Priadia, T.; Hiziroglub, S. 2013. Characterization of heat treated wood species. Materials \& Design 49: $575-582$.

Rowell, R.M.; Ibach, R.E.; Mc Sweeny, J.; Nilsson, T. 2009. Understanding decay resistance, dimensional stability and strength changes in heat treated and acetylated wood. Wood Material Science and Engineering 4 (1-2): 14-22.

Sjöström, E. 1981. Fundamentals and Applications, in: Wood chemistry, Wood polysaccharides. Academic Press, New York (USA), Chapter 3: 49-67.

Stamm, A.J. 1956. Thermal Degradation of Wood and Cellulose. Industrial and Engineering Chemistry 48 (3): 413-417.

Tjeerdma, B.F.; Militz, H. 2005. Chemical changes in hydrothermal treated wood: FTIR analysis of combined hydrothermal and dry heat treated wood. European Journal of Wood and Wood Products, 63: 102-1.

Unsal, O.; Korkut, S.; Atik, C. 2003. The effect of heat treatment on some properties and colour in eucalyptus ((Eucalyptus camaldulensis Dehn.) wood. Maderas. Ciencia y Tecnologia 5 (2): 145-152.

Welzbacher, C.R.; Brischke, C.; Rapp, OA. 2007. Influence of treatment temperature and duration on selected biological, mechanical, physical and optical properties of thermally modified timber. Wood Material Science and Engineering 2: 66-76.

Yildiz, S.; Gezer, E.D; Yildiz, U.C. 2006. Mechanical and chemical behavior of spruce wood modified by heat. Building and Environment 41: 1762-1766. 